\title{
Determination by Landsat Satellite Imagery to Local Scales in Land and Pollution Monitoring: A Case of Buyuk Melen Watershed (Turkey)
}

\author{
Ipek F. Barut ${ }^{* 1}$, Hulya Keskin Citiroglu ${ }^{2}$, Murat Oruc ${ }^{3}$, Aycan M. Marangoz ${ }^{4}$ \\ ${ }^{1}$ Institute of Marine Sciences and Management, Istanbul University, Muskile S. 2 Vefa, Istanbul, Turkey \\ e-mail: barutif@istanbul.edu.tr \\ ${ }^{2}$ YIKOB Investment Monitoring and Coordination Presidency, İnönü Bulvarı No. 4 Bakanlıklar, Aydin, \\ Turkey \\ e-mail: keskinhc@gmail.com \\ ${ }^{3}$ Geomatics Engineering Department, Bulent Ecevit University, İncivez Mh., 67100, Zonguldak, Turkey \\ e-mail: orucm@ hotmail.com \\ ${ }^{4}$ Geomatics Engineering Department, Bulent Ecevit University, İncivez Mh., 67100, Zonguldak, Turkey \\ e-mail: aycanmarangoz@hotmail.com
}

Cite as: Barut, I. F., Keskin Citiroglu, H., Oruc, M., Marangoz, A. M., Determination by Landsat Satellite Imagery to Local Scales in Land and Pollution Monitoring: A Case of Buyuk Melen Watershed (Turkey), J. sustain. dev. energy water environ. syst., 3(4), pp 389-404, 2015, DOI: http://dx.doi.org/10.13044/j.sdewes.2015.03.0029

\begin{abstract}
Buyuk Melen Watershed provides drinking water from the Western Black Sea region to Istanbul province, which Buyuk and Kucuk Melen rivers, Asar, Ugur and Aksu rivers. Many settlement areas, fertilized agricultural lands, industrial plants and solid/liquid waste dumping areas have present in Melen watershed, causing substantial pollution problems. Melen watershed has been at a serious risk of pollution that a lot of settlement areas, agricultural lands, industrial facilities, and solid and liquid waste. In this study, LANDSAT satellite data was used to monitor the status of this area on the potential of the region studied. In the watershed change of 1987, 2001, 2006 and 2010 and also supported by satellite data. However, contaminants in the watershed discharges to the inner parts as shown from the satellite data have also been observed that the increase in pollution.
\end{abstract}

\section{KEYWORDS}

Buyuk Melen Watershed (Turkey), Drainage network, LANDSAT remote sensing data, Land used, Riverbed change, Temporal changes.

\section{INTRODUCTION}

Monitoring major natural phenomena by remote sensing is important in that it avoids a recurrence of the damage that incur or may incur and results in minimum damage $[1,2]$. Advanced technologies such as Remote Sensing (RS) and Geographic Information Systems (GIS) are used on a global scale to monitor land use/change, to manage land, to identify environmental changes, to evaluate their effects, and to preserve water resources [3]. The method is effective in monitoring not only the current status but also the process as well. Determining and monitoring periodic changes by remote sensing facilitate strategies are directed at planning and managing geographical spaces. Land use in our country is undergoing rapid change. In particular, deforestation, the use of forest land in a manner inconsistent with its features, the potential transformation of forest land aimed at opening up agricultural or pasture areas and for other purposes provide prime examples of this changes.

\footnotetext{
${ }^{*}$ Corresponding author
} 
Water and sediment pollution are caused by industrialisation, urbanisation, population growth and the use of pollutants such as crop protection products called agrochemicals and fertilisers. Industrial activity has a much greater effect on the environment than other factors. The pollutants may include domestic and industrial water waste discharged into water bodies from one specific or more points. Apart from these pollutants, stream or river flow rate, precipitation, temperature and the amount of sediment also affect water quality. Therefore, a very close relationship exists between the water quality of a stream or river and hydrodynamic and hydrological processes. Since stream flow rate is effective in diluting and transporting pollutants carried into these environments, it may reduce the effect of pollution. Precipitations cause streams and rivers to be considerably polluted by surface runoff. Temperature affects marine life in streams and rivers. Sediments formed through erosion are discharged into water bodies and change the streambed, which in turn affects the hydrological features of the river or stream.

Using the technology of GIS, this study aims to investigate the possibility of changes that occurred over time in the features of the Buyuk Melen Watershed and to discuss the reasons on the basis of Landsat satellite images taken in 1987, 2001, 2006 and 2010. The study area (Figure 1) consists of a medium-sized basin. This study evaluates the burden caused by pollutants which are prevalent in this basin by means of Landsat imaging techniques.
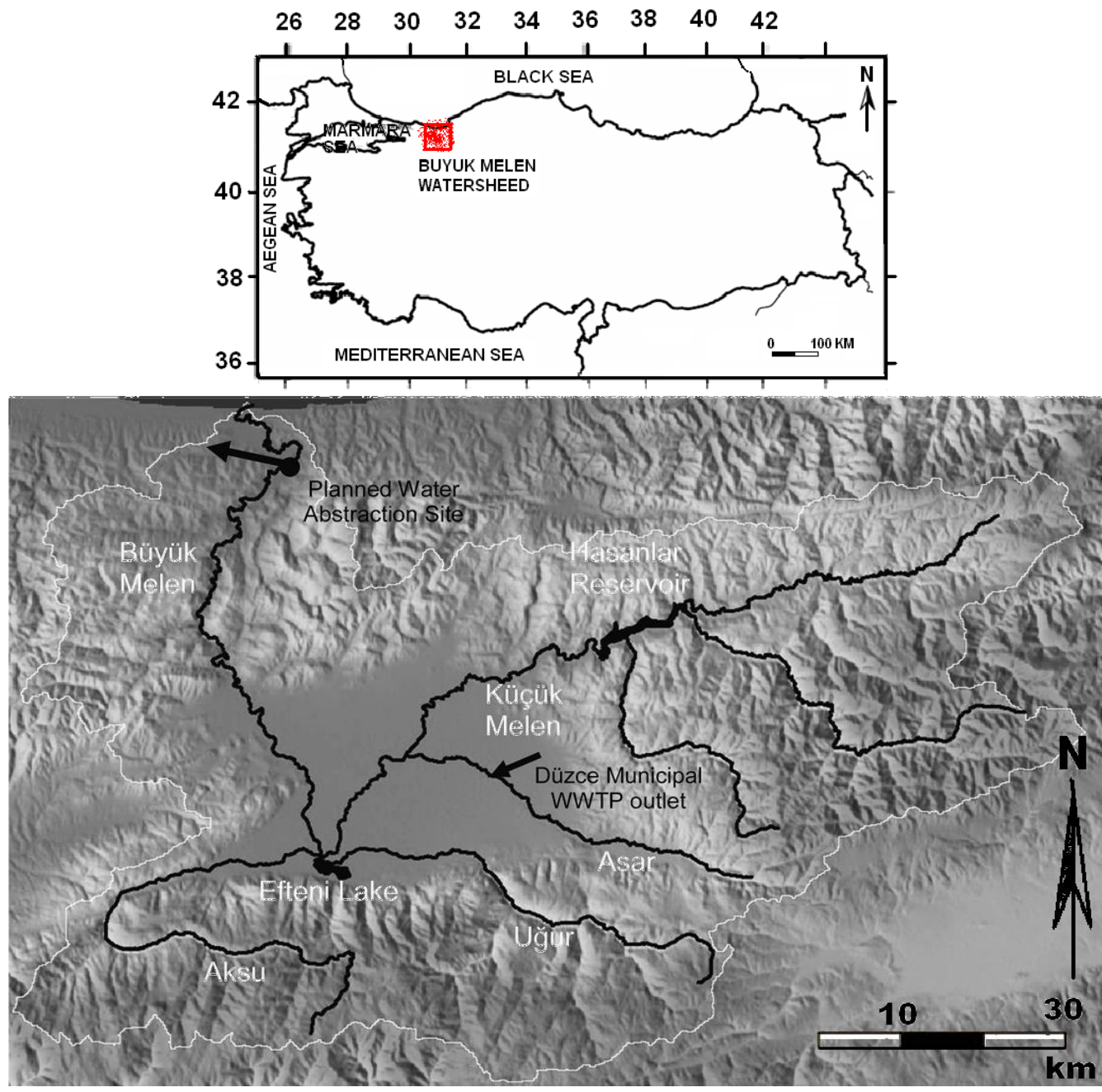

Figure 1. Location map of the Buyuk Melen watershed basin 
It is the first project was conducted on the Buyuk Melen Watershed [4] and evaluation water quality in 2008. The Buyuk Melen Watershed is the first example of water transportation between basins to supply additional drinking water to Istanbul, a city of over 15 million people. Drinking water $\left(8.5 \mathrm{~m}^{3} / \mathrm{sec}\right)$ was transported for the first time by this project. The study on meeting the long-term drinking water needs of Istanbul was planned and executed by the General Directorate of State Hydraulic Works (DSI). The Greater Istanbul Water Supply Project in Melen System Project consisted of four phases. The Buyuk Melen Watershed Integrated Project of Water Management and Preservation was completed in 2008 as the first and second stages of the Melen System of The Greater Istanbul Water Supply Project [5].

The first stage included the construction of a Water Intake Weir on the Buluk Melen River for $8.5 \mathrm{~m}^{3} / \mathrm{sec}$ (268 million $\mathrm{m}^{3} /$ year) water to be supplied. After pumping, water was transferred to water treatment plant with a capacity of $720,000 \mathrm{~m}^{3} /$ day. Melen River which flows into the Black Sea to the north, approximately $7 \mathrm{~km}$ from the mouth of the river which was built for the upstream section of the river, the regulator (Melen regulator) was inserted. This water would be controlled manner, and from the Melen pumping station would be sent to the Melen Advancement Tank by advancement line $(1.7 \mathrm{~km})$. Then various tunnel (derivation/conduit) structures and to the treatment plant was transmitted to the transmission line $(129.6 \mathrm{~km})$. In the second stage Buyuk Melen Dam and by the second pipeline, as 307 million $\mathrm{m}^{3} /$ year of water transmission, by increasing the capacity of the pump to a new treatment plant has been completed.

More recently, in the third phase of the ongoing work on the project, of water transmission $307 \mathrm{hm}^{3} /$ year by the third pipeline, increasing the capacity of this a pump, and the addition of a new water treatment plant is located. In the fourth stage: which would be additions to structures to the pumping stations to convey water such as 308 $\mathrm{hm}^{3} /$ year, wastewater treatment plant (with a capacity of $800,000 \mathrm{~m}^{3} /$ day added) as with and additional to be made the energy supply system. The final stage of the study will meet the requirement of Istanbul until 2040 from approximately 1,180 million $\mathrm{m}^{3}$ of water.

As a natural result of deforestation, the area is suffering from soil erosion and the amount of solid material in streams is steadily increasing. In fact, an average of 178,284 tons of solid material is discharged into the Black Sea by the Buyuk Melen stream per year [6]. As human settlement and industrialisation in the stream basin is increasing rapidly, water quality is affected in an unfavourable manner [7] and different agricultural activities bring about pollution of different concentrations. The highest amount of nitrogen dispersed across the Buyuk Melen Watershed comes from agricultural activities and phosphorous from animal husbandry. In recent years, with increasing cultivation of Virginia tobacco in Duzce Plain, there has been an increase in water pollution due to the use of pesticides and herbicides [5].

Similarly, siltation from The Melen Regulator (Figure 1) installed on the Buyuk Melen leads to water efficiency and quality loss, aquatic habitat degradation, and similar unfavourable consequences. This indicates that the water quality of the streams in the Buyuk Melen Watershed Basin is degrading with each passing day. Since 2009 the water quality of the Buyuk Melen Stream which supplies drinking and domestic water has been inevitably undergoing degradation by to industrial installations, human settlement and agricultural activities.

The studied area has advanced forestry products and weapons industries. In fact, in the area, there are about 300 forestry products factories, 14 of which are large-scale ones, and 70 weapons factories. Moreover, the D-100 highway connecting Ankara with Istanbul and running through the basin has also enlivened the area. Furthermore, domestic wastewater from over 100 accommodation facilities in the basin and grease wastes from washing and lubrication stations pose a major threat. Although the forestry 
products and weapons industries do not have a significant effect in terms of water pollution because they do not discharge liquid processing wastes, they nevertheless produce domestic waste. Duzce has a biological waste water treatment plant. However, only two installations have a waste treatment unit. The other townships and regions except for Duzce discharge their waste water into nearby rivers, which makes it inevitable for the Buyuk Melen Stream to become polluted.

\section{FEATURES OF THE STUDY AREA}

The study area lies $16 \mathrm{~km}$ to the northwest of Duzce and $9 \mathrm{~km}$ to the west of Akcakoca in the Black Sea region of Turkey. It borders the Black Sea to the north and Duzce Plain to the south. The boundary of the study area was determined on the basis of geomorphological criteria. Therefore, as the centre of the Melen Strait drainage basin, the hills in its immediate vicinity and part of the Melen Stream where it flows into the Black Sea form the boundary of the study area. Around $80 \%$ of the Melen Watershed Basin (Figure 1) lies within the boundaries of Duzce Province. Therefore, it was assumed that this province characterises the basin on a large scale. The remaining small portion of the basin lies within the borders of Sakarya, Bolu and Zonguldak Provinces. The Buyuk Melen Watershed has an area of $470 \mathrm{~km}^{2}$.

The study area is located between $30^{\circ} 47^{\prime}$ and $31^{\circ} 23^{\prime}$ east longitude and $40^{\circ} 44^{\prime}$ and $41^{\circ} 05^{\prime}$ north latitude. The elevation of the Duzce plain in the area is approximately $120 \mathrm{~m}$. In the southern and eastern portions of the basin, the elevation reaches $1,900 \mathrm{~m}$. The basin has mild winter and spring months, whereas the summers are hot and dry. The summer months are semi-arid with little rainfall. The Buyuk Melen basin has an average annual precipitation of $537 \mathrm{~mm}$. Annual average temperature in the region is $13.5^{\circ} \mathrm{C}$. The hottest month is July $\left(42.4{ }^{\circ} \mathrm{C}\right)$, the coldest month is December $\left(-16.5^{\circ} \mathrm{C}\right)$. In the Aksu stream and Ugur stream basins, which are located in the area, snow in winter does not thaw out completely until June.

\section{Geological setting}

It was determined based on the geochemistry of the suspended and bed sediments that some rocks in the Buyuk Melen Watershed Basin were greywacke and literanite before they were exposed to weathering $[8,9]$.

The lithological units occurring in the study area consist of, in order of age from the oldest to the youngest, Cakraz, Akveren, Yigilca, Caycuma and Orencik formations and Quaternary alluvium (Figure 2). The Cakraz formation, which is the oldest formation lying to the west of a small portion in the study area is made up of massive and medium thickness red, purple layers of conglomerate, sandstone, siltstone and shale [10]. It is of Permian-Triassic age [11]. The unit about $200 \mathrm{~m}$ in thickness is overlain by angular unconformity with the Akveren formation on top of it. The Akveren formation occurring locally to the northwest, southeast and south of the study area is composed of clayey limestone, claystone, marl, sandstone, reef limestone and volcanites. The dominant colours of the unit are yellow, white, greyish green and reddish white. The unit having a thin-medium-thick layer is of Upper Campanian-Lower Eocene age [10]. The Akveren formation is overlain by Lower-Middle Eocene $[10,12]$ Yigilca and Caycuma formations. The Y1gilca formation comprising andesite, basalt, tuff, agglomerate and volcanogenic sandstone has a thickness ranging from $100-1,000 \mathrm{~m}$. It passes laterally and vertically into the Caycuma formation. The Caycuma formation, which constitutes a large portion of the study area, is made up of a sequence of sandstone, siltstone, claystone and shale. The sandstones are light yellowish green in colour and of thin-medium thickness. The siltstone and claystone levels have a light greenish grey colour and are thin-medium in 
thickness. The sandstones containing volcanic material are made up of thicker layers and are cemented with carbonate. The unit $1,000 \mathrm{~m}$ in thickness is overlain by angular unconformity with the Orencik formation of Pliocene age and Quaternary alluvium above $[10,12]$.

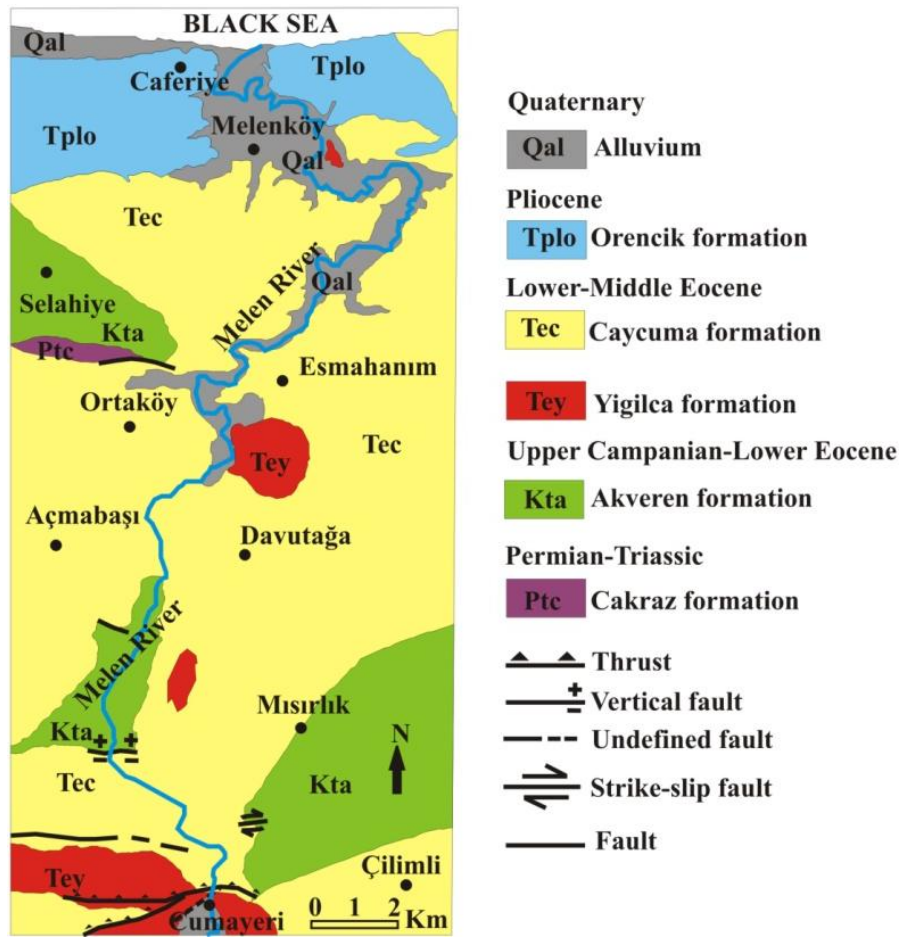

Figure 2. Geological map of study area [modified from 10, 12-14]

The Orencik formation is composed of a red, yellowish red and brown sequence of conglomerate, sandstone and mudstone. The unit displaying medium-thick bedding has a thickness in the range of 50-100 m. The Orencik formation which unconformity overlies all the units older than it was established to be Pliocene age based on its strategic position [13]. The Quaternary alluvium, which is the youngest unit in the study area, comprises of gravel, sand and mud sediments on flat areas developed mainly on river beds and old depressions.

\section{Structural geology and lineament analysis}

The North Anatolian Fault Zone (NAFZ) [15] is bound by an active right-lateral strike-slip transform plate 1,600 km in length [16]. In the study area lies the Duzce Fault line, which constitutes the east branch of NAFZ in the north and triggered a 7.2 magnitude earthquake on November $12^{\text {th }}$, 1999. Along with the Duzce Fault line, the Karadere, Hendek and Cilimli faults are the main elements of the area tectonics.

Many studies have been conducted which investigate lineament for geological purposes using satellite images and shaded relief data $[17,18]$. The methods make it possible to provide insights into the area in a speedy and economical way. Following improvements and filtrations, lineaments were identified by means of Landsat ETM+ satellite images [19, 20] (Figure 3). This study produced a total of 24 linear structures. Similarly, in the anticline synclinal and thrust zones, structures exist that are parallel and vertical to the NAFZ. The point that should be noted here is that the lineaments that were obtained were overlapped with the maps made by [10, 12-14], and are indicative of active/inactive faults in the area that represent linear structures. 


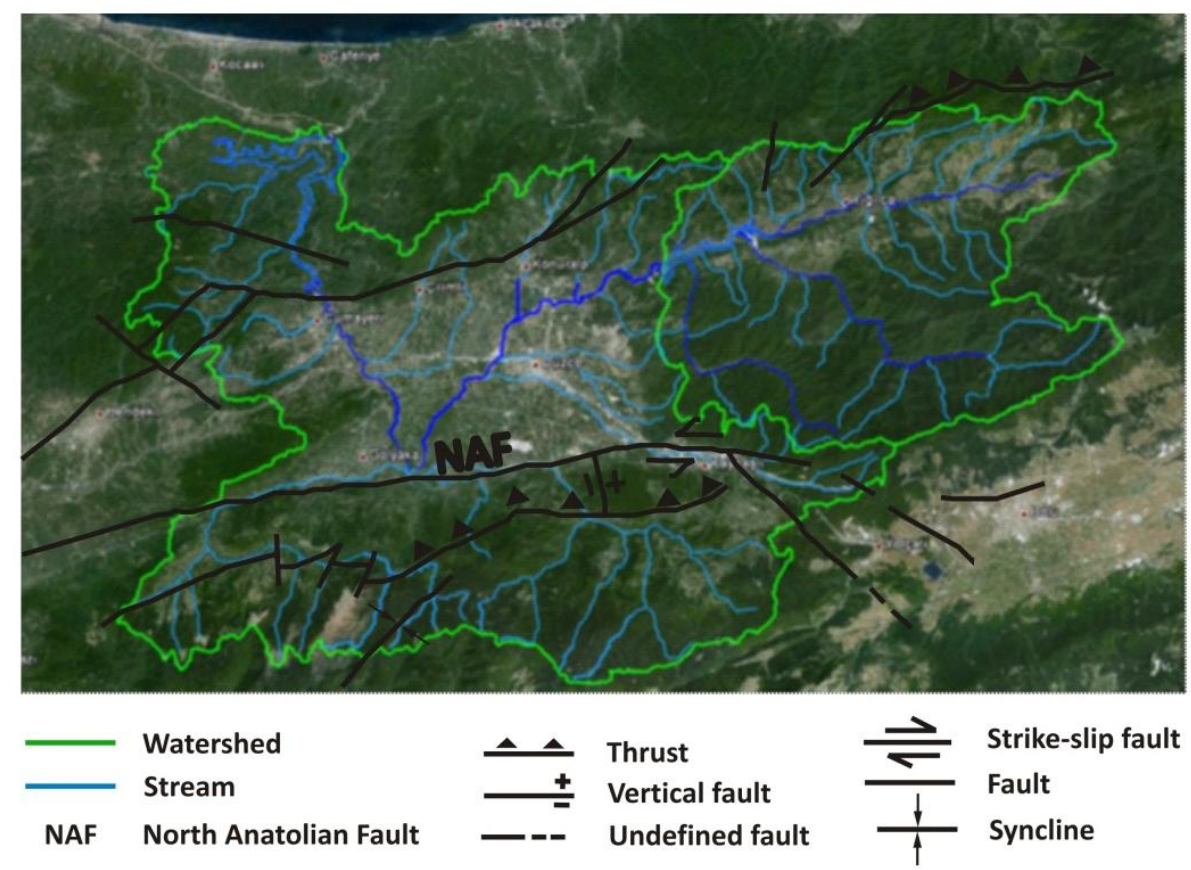

Figure 3. Determined using of lineaments of classical and by [10, 12-14]

The main factors causing changes in water level and level of base falling of a stream are geological structure, tectonic movements, diminution material from valley to structure high buildings, an increase in the drag force at the river bed owing to the increasing water level of flood bed to block the passing of solid material, narrowing the riverbed and shortening the length of the stream. As a natural result of water level and base falling off a stream and tectonic-epirogenic factors have pollution loads increase. Cracked and fracture systems that occurred by tectonism affect water levels (surface and groundwater), water transition and flow rate of the water. Moreover considering the fact that Buyuk Melen Watershed forms alluvial and colluvial soils, the alluvial aquifers are very sensitive to the river pollution.

\section{Features of the soil}

A large portion of the Duzce Basin is covered with flysh sequences of Mesozoic and Cenozoic ages. These units which comprise of sequences of clay, claystone, sandstone, conglomerate, marl and in parts limestone are poor in ground water. This is because, as the formation contains clay, precipitation water runs off the surface and reaches flood beds and streams without being filtrated into the soil. Silurian-Devonian pyrite and ores such as iron are present as well as rocks such as Upper Cretaceous gneiss, mica schist and amphibolite. In general, brown limeless forest soils are widespread along with yellow/red podzolics and lightly podzolic soil. The soil is medium in depth [21].

\section{DATA AND METHOD}

Landsat 5 TM satellite images of 1987 and 2010, Landsat 7 ETM+ satellite images of 2001 and 2006 were used as data relating to the study area. These images were subjected to image processing analysis using remote sensing approaches.

Optical satellite images have been obtained from optical sensors used in satellite image systems. Some satellite images used in this study are affected by cloud cover. These images can be affected by adverse weather conditions and cloud optical satellite images. We could not obtain or interpret the structure of the land area obscured by cloud 
cover. Therefore, data on the land cover in some parts of the cloud-covered regions is not included in this process. The cloudy displays are Landsat images of 1987, 2006 and 2010. The proportion of cloud was determined to be $0.06 \%$ in the 1987 images, $1.71 \%$ in the 2006 images and $4.02 \%$ in the 2010 images.

\section{Remote sensing technology}

Remote sensing, without any contact, is the science of acquiring information about the Earth's surface using sensor systems. Aerial photographs and satellite imagery are the main data of sources remote sensing. Today, these remote sensing data, is provided by the airborne, unmanned aerial vehicles and satellites equipped with cameras and sensors. Cameras and sensors on platforms, measure the reflected and emitted energy from the Earth's surface using the certain areas of electromagnetic spectrum and form the image.

This energy is called electromagnetic energy and it is the main energy source for remote sensing technology. Visible light, radio waves, heat, ultraviolet rays and X-rays are the many forms of electromagnetic energy. These electromagnetic energies radiate in accordance with a basic wave theory which can be described as $c=v \times \lambda$ in which $c$ is the constant means the velocity of light; $v$ is the frequency of the wave and $\lambda$ is the wavelength of the wave, and both of them can be used to categorise the wave [23]. The electromagnetic wave in remote sensing is commonly defined by itself as wavelength range in the electromagnetic spectrum (Figure 4).

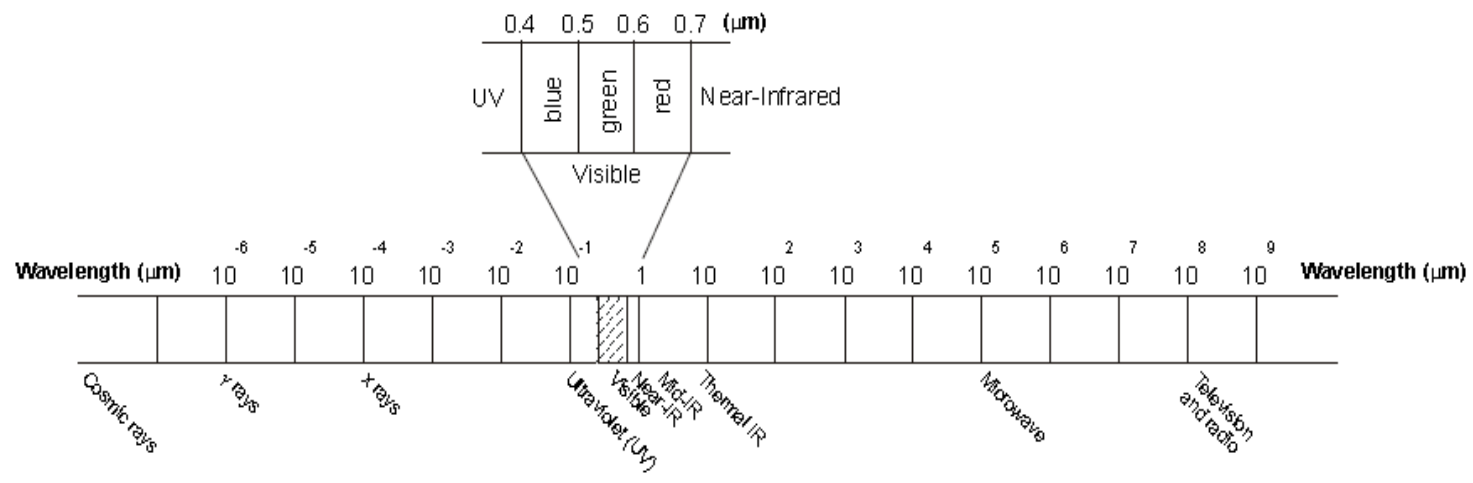

Figure 4. Electromagnetic spectrum [23]

Sensor systems in remote sensing can take information about Earth's surface objects from such sections of the electromagnetic spectrum as the visible, infrared, microwave, etc. Many Earth's surface objects give very distinct spectral reflectance and emittance features, and spectral reflectance curves can show this. In this technology, features of Earth's surface should have separable spectral reply patterns if they need to be sort spectrally [23].

\section{Dataset}

The Landsat imaging system has TM and ETM sensors providing images at different wavelengths of the electromagnetic spectrum and at different spectral intervals in 7 spectral bands. The first 3 bands in the images occur at wavelengths containing the red, green and blue colours - the 4 band in the infrared region, the 6 band in the thermal region and the 7 band in the far infrared region. The properties of these different spectral bands that are formed make it possible to classify different land types. For instance, the $4^{\text {th }}$ band can easily identify forest and water structures by near infrared sensing and the $5^{\text {th }}$ and $7^{\text {th }}$ bands can reveal various geological structures. Radiometric characteristics and feature extraction of Landsat satellite images are given in Tables 1 and 2. 
Table 1. Radiometric characteristics of the utilized dataset for used satellite images

\begin{tabular}{|c|c|c|c|}
\hline Date & Satellite & Spectral resolution $[\mu \mathrm{m}]$ & Spatial resolution [meters] \\
\hline \multirow{6}{*}{ 18.09.1987 } & \multirow{6}{*}{ Landsat $5 \mathrm{TM}$} & $0.45-0.52$ Blue & 28.5 \\
\hline & & $0.52-0.60$ Green & 28.5 \\
\hline & & 0.63-0.69 Red & 28.5 \\
\hline & & 0.76-0.90 Near IR & 28.5 \\
\hline & & 1.55-1.75 Mid IR & 28.5 \\
\hline & & 2.08-2.35 Mid IR & 28.5 \\
\hline \multirow{6}{*}{ 12.06.2001 } & \multirow{6}{*}{ Landsat 7 ETM+ } & $0.45-0.52$ Blue & 28.5 \\
\hline & & $0.52-0.60$ Green & 28.5 \\
\hline & & 0.63-0.69 Red & 28.5 \\
\hline & & $0.76-0.90$ Near IR & 28.5 \\
\hline & & 1.55-1.75 Mid IR & 28.5 \\
\hline & & 2.08-2.35 Mid IR & 28.5 \\
\hline \multirow{6}{*}{ 12.07.2006 } & \multirow{6}{*}{ Landsat ETM+ } & 0.45-0.52 Blue & 30 \\
\hline & & $0.52-0.60$ Green & 30 \\
\hline & & 0.63-0.69 Red & 30 \\
\hline & & 0.76-0.90 Near IR & 30 \\
\hline & & 1.55-1.75 Mid IR & 30 \\
\hline & & 2.08-2.35 Mid IR & 30 \\
\hline \multirow{6}{*}{ 13.06.2010 } & \multirow{6}{*}{ Landsat $5 \mathrm{TM}$} & $0.45-0.52$ Blue & 30 \\
\hline & & $0.52-0.60$ Green & 30 \\
\hline & & 0.63-0.69 Red & 30 \\
\hline & & 0.76-0.90 Near IR & 30 \\
\hline & & 1.55-1.75 Mid IR & 30 \\
\hline & & 2.08-2.35 Mid IR & 30 \\
\hline
\end{tabular}

Table 2. Phenomena revealed by different bands of Landsat TM and Landsat ETM+ data

\begin{tabular}{|c|c|c|}
\hline Satellite & Band & Phenomena revealed \\
\hline & $\begin{array}{l}0.45-0.52 \mu \mathrm{m} \\
\text { (visible blue) }\end{array}$ & $\begin{array}{l}\text { Shorelines and water depths } \\
\text { (these wavelengths penetrate water) }\end{array}$ \\
\hline & $\begin{array}{l}0.52-0.60 \mu \mathrm{m} \\
\text { (visible green) }\end{array}$ & $\begin{array}{l}\text { Plant types and vigor (peak vegetation reflects these } \\
\text { wavelengths strongly) }\end{array}$ \\
\hline \multirow[t]{2}{*}{ Landsat $5 \mathrm{TM}$} & $\begin{array}{l}0.63-0.69 \mu \mathrm{m} \\
\text { (visible red) }\end{array}$ & $\begin{array}{l}\text { Photosynthetic activity (plants absorb these } \\
\text { wavelengths during photosynthesis) }\end{array}$ \\
\hline & $\begin{array}{l}0.76-0.90 \mu \mathrm{m} \\
\quad(\text { near IR) }\end{array}$ & $\begin{array}{l}\text { Plant vigor (healthy plant tissue reflects } \\
\text { these wavelengths strongly) }\end{array}$ \\
\hline \multirow[t]{3}{*}{ Landsat 7 ETM+ } & $\begin{array}{l}1.55-1.75 \mu \mathrm{m} \\
\quad(\text { mid IR) }\end{array}$ & $\begin{array}{l}\text { Plant water stress, soil moisture, rock types, cloud } \\
\text { cover vs. snow }\end{array}$ \\
\hline & $\begin{array}{l}10.40-12.50 \mu \mathrm{m} \\
\quad \text { (thermal IR) }\end{array}$ & Relative amounts of heat, soil moisture \\
\hline & $2.08-2.35 \mu \mathrm{m}(\mathrm{mid}$ IR $)$ & Plant water stress, mineral and rock types \\
\hline
\end{tabular}

\section{Data processing}

In order to analyse different data sets, such as satellite sensor data collected at various time periods, or data collected from different satellite sensors, maps and images, all the images were rectified into the same coordinate system $[24,25]$. This coordinate system can be a reference plane defined on a map projection, or an image coordinate system. All images were transformed in the UTM (Universal Transverse Mercator). In general, the $1^{\text {st }}$ degree affine transformation was used for geometric transformation of the satellite data [26]. In this study, the $1^{\text {st }}$ degree polynomial transformation method with a standard deviation of 0.5 pixels was used for the geometric transformation of the satellite images collected at different time intervals. 


\section{Image classification}

The basic assumption for image classification is that a specific part of the feature space corresponds to a specific class. Once the classes have been defined in the feature space, each image pixel can be compared to these classes and assigned to the corresponding class. Classes to be distinguished in an image classification need to have different spectral characteristics. This can be analysed by comparing spectral reflectance curves. But if classes do not have distinct clusters in the feature space, image classification can only give results to a certain level of reliability. The principle of image classification is that a pixel is assigned to a class based on its feature vector, by comparing it to predefined clusters in the feature space. Doing so all image pixels result in a classified image [27]. Generally classifying means assigning a number of objects to a certain class according to the class's description. Therefore a class description is a description of the typical properties or conditions the desired classes have.

The objects then become assigned (classified) according to whether they have or have not met these properties/conditions. In terms of database language, one can say the feature space is segmented into distinct regions which lead to a many-to-one relationship between the objects and the classes. As a result each object belongs to one definite class or to no class [28].

In the image classification, supervised classification algorithm (Maximum-Likelihood Classification-MLC) was applied respectively to the Landsat images based on the determined training patterns and reference materials in the region. For classification analysis of each Landsat image, the same training sites were utilised with the same colour information. During the classification procedures of Landsat images, reference datasets were employed including high resolution aerial photos, topographic maps, high resolution satellite images and personal knowledge about the area. Detailed information about reference dataset can be found elsewhere [29, 30]. Figure 5 gives land classes identified by means of imaging classification and variations in values for classifications are given in Table 3.

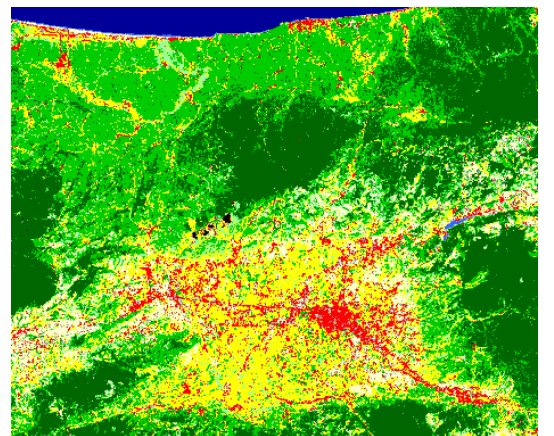

classified on the Landsat image in 1987

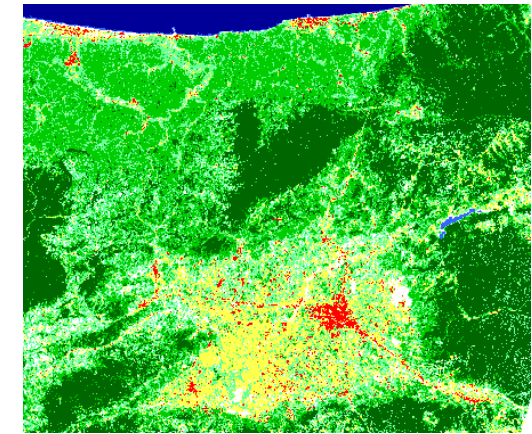

classified on the Landsat image in 2001

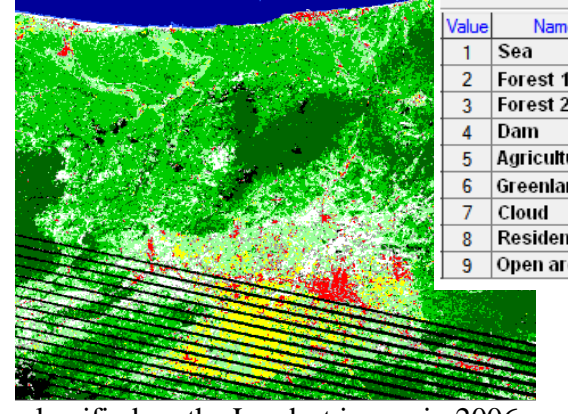

classified on the Landsat image in 2006

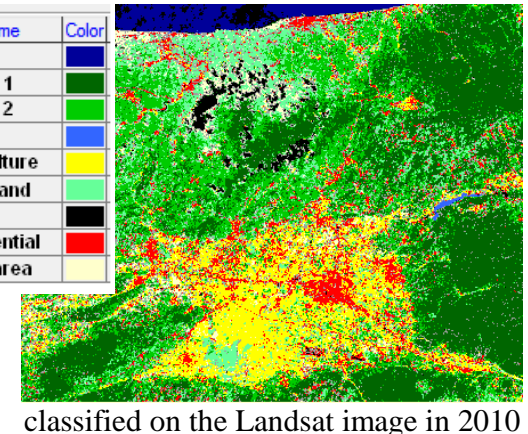

classified on the Landsat image in 2010

Figure 5. Changes in land use between years 1987-2010 
Table 3. The temporal changes land use in Melen Watershed Basin (year 1987, 2001, 2006, 2010)

\begin{tabular}{|c|c|c|c|}
\hline Year & Land use in & Dispertion [\%-pixel] & Area $\left[\mathrm{km}^{2}\right]$ \\
\hline \multirow{6}{*}{1987} & Agriculture & $16.20-392,799$ & 319.05 \\
\hline & Forest & $27.12-657,528$ & 534.08 \\
\hline & Pasture and meadows & $33.77-818,659$ & 664.96 \\
\hline & Water surface & $0.15-3,751$ & 3.05 \\
\hline & Residential & $7.41-179,529$ & 145.82 \\
\hline & Country side & $11.80-286,166$ & 232.44 \\
\hline Total pixel-area & & $2,424,384$ & $1,969.21$ \\
\hline \multirow{6}{*}{2001} & Agriculture & $10.38-251,691$ & 204.44 \\
\hline & Forest & $30.04-728,270$ & 591.54 \\
\hline & Pasture and meadows & $40.63-984,906$ & 799.99 \\
\hline & Water surface & $0.23-5,656$ & 4.59 \\
\hline & Residential & $3.14-76,086$ & 61.80 \\
\hline & Country side & $12.10-293,345$ & 238.27 \\
\hline Total pixel-area & & $2,424,384$ & $1,969.21$ \\
\hline \multirow{6}{*}{2006} & Agriculture & $4.12-90,210$ & 81.19 \\
\hline & Forest & $26.01-568,993$ & 512.09 \\
\hline & Pasture and meadows & $42.23-923,675$ & 831.31 \\
\hline & Water surface & $0.25-5,435$ & 4.89 \\
\hline & Residential & $3.27-71,580$ & 64.42 \\
\hline & Country side & $11.44-250,329$ & 225.30 \\
\hline Total pixel-area & & $2,187,453$ & $1,968.71$ \\
\hline \multirow{6}{*}{2010} & Agriculture & $9.93-217,225$ & 195.50 \\
\hline & Forest & $27.72-606,452$ & 545.81 \\
\hline & Pasture and meadows & $35.25-771,117$ & 694.01 \\
\hline & Water surface & $0.14-2,963$ & 2.67 \\
\hline & Residential & $10.46-228,904$ & 206.01 \\
\hline & Country side & $10.17-222,428$ & 200.19 \\
\hline Total pixel-area & & $2,187,453$ & $1,968.71$ \\
\hline
\end{tabular}

\section{RESULTS}

As is evident from Figure 5 and Table 3, some variations were observed in land classifications in relation to time. In particular, this variation is evident in the classification of residential areas and water surfaces. The total area of $1,969.21 \mathrm{~km}^{2}$ in 1987 has decreased to $1,968.71 \mathrm{~km}^{2}$ in 2001 .

As Figure 6 illustrates, the distribution of the overall agricultural area falls by 123.55 $\mathrm{km}^{2}$ (38\%) from 1987 to 2010 . The smallest area was identified in 2006 with $81.19 \%$ and the distributions observed in 2010 and 2001 were established to be similar. As for the forest areas, it was at its highest level in 2001, whereas it decreased by $8 \%$ in 2006 . The distribution of pasture and meadows exhibited an upward trend from 1987 to 2010. The distribution increased by $20 \%$ from 1987 to 2001 and it was at its highest in 2006. There are evident variations in pasture and meadow areas. The general distribution increased by $30 \%$ from 1987 to 2010 as compared to a decline of $16.5 \%$ from 2006 to 2010.

The residential areas exhibit considerable temporal variations. Despite of being at its lowest in 2001, it reached its highest level in 2010. There was an increase of $30 \%$ in its overall distribution from 1987 to 2010. The residential areas reached a stunning level (219\%) from 2006 to 2010 with an increase of $141.59 \mathrm{~km}^{2}$. The distribution of rural areas displayed a downward trend from 1987 to 2010. It experienced a decrease of $16 \%$ in 2010, down from its highest level in 2001. 


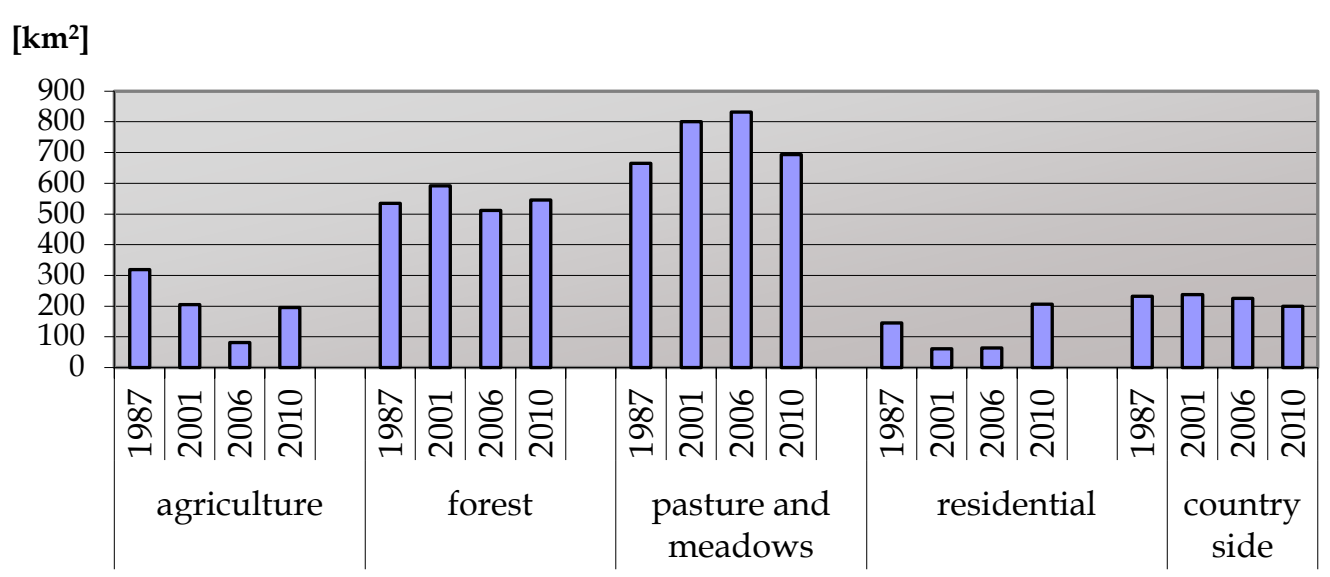

Figure 6. The temporal changes (1987-2010) in agricultural, forest, pasture, meadows, residential, country side areas

It was established that the residential areas decreased from 1987 to 2001 and midterm of 2006 as seen in Table 3 and Figures 5 and 6. However, an increase is shown in later 2006. The rate of increasing rose highly in 2010 compared to 2001 and 2006. Buyuk Melen Watershed contained in this area was affected by Marmara and Duzce earthquakes in 1999. After these earthquakes, soil survey was made and projects were produced for permanent settlement. Republic of Turkey Prime Ministry, Turkish Housing Development Administration (TOKI) built modern buildings for rights owners whose houses were destroyed in the earthquake. Furthermore, a large part of the settlement area was demolished by the authorities and as part of the reconstruction efforts, new houses were built. The process of destruction and reconstruction continued between 2001 and 2005, accounting for differences in the distribution of residential areas.

The temporal variation in the water level (Figure 7) displayed an upward trend from 1987 to 2006. By comparison, it started to decline in 2010. An increase of 55\% was observed in the overall distribution of water surface from 1987 to 2006 as compared to a decrease of $45 \%$ in 2010. In making classifications, cloudiness in the images was taken into consideration and the cloudy areas in the images were identified. Accordingly, as no information could be obtained on the land covers beneath the cloudy sections, its effects were considered in making classifications.

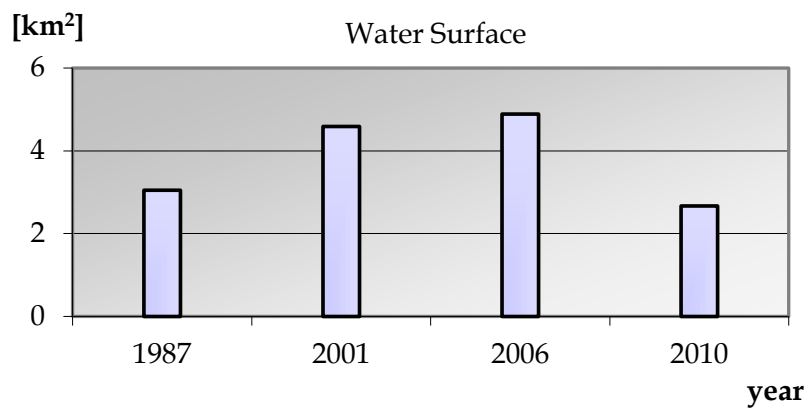

Figure 7. The temporal changes (1987-2010) water surface

\section{DISCUSSION}

There have been natural disasters, landslides, land located within a close relationship between the people who are drawn up according to the needs. The man's activities in this direction grazing, agriculture, forestry trenches, grouped under the headings of natural 
resource consumption and engineering studies [31]. Landslides, the impact on these titles, the knowledge on the subject, vary according to the needs and economic factors. There are contrary to the potential uses of the land, caused by natural disasters occurring in many parts of the world. Although this made disasters, aimed at controlling the high costs of engineering structures and rational land use plans reduces the difficult situation of much of the country's economy [32]. In this respect, an important feature of the land opened for use in the destruction of natural vegetation in agricultural areas, particularly in the areas of agriculture nuts, landslides in the entire field, $66.7 \%$ developed on these areas. It was destroyed in the areas of vegetation change brought with it an important indicator of dire consequences [33].

Another important system is, the rainfall has a large impact on the basin. This influences the effectiveness of regional precipitation within the basin runoff exceeds of threshold values may result in a possible landslide triggering. In a study into the investigation area in the region [33] stream power index distribution of abrasive stream power index calculated minimum and maximum values were in the range of 0 to 9.8 . This means that: Melen River, combined with high abrasion strength will take effect for the side arms. The distribution of landslides by stream erosion classes in the field strength values between $0-2$ are up $85 \%$ of all the land in the mountainous areas [33].

Compared to the results obtained in the basin of the rivers, especially around the temporal variation of the intensity of agriculture and natural vegetation was remarkable between years of 1987-2010. This will affect the content and the density of the material carried by the stream drainage network and result in abnormalities. However, the basin contained industrialisation, urbanisation, population growth and the significant sources of pollution, such as pesticides and chemical fertilisers, the negative impact on the environment was much more than other factors.

The pollutant loads from point sources alone are not enough for the evaluation of the pollution in Melen Watershed. The preliminary results for the diffusion of pollution loads indicate that the point sources account for $35 \%$ and $40 \%$ of the total nitrogen and phosphorus loads, respectively [34]. Although the diffused sources seem to be more important in the pollution loads, due the problems related to the management and control of diffuse pollution, treatment and hence the control of point sources may provide a better or at least a faster solution to the pollution problem in Melen Watershed.

Intensive urbanisation and population growth in the region continues to grow exponentially in the production of domestic waste water was clear. Therefore, this kind of human-induced environmental pollution will increase rapidly. The reach of saturation the development of indigenous people to raise their standard by living will enable the efficient use of available water resources and the implementation of an environmental management system is very difficult. Nevertheless, studies related to the subject on one hand to control population growth, and urbanisation on the other hand the development of emergency action plans and strategies for the future-oriented resource management was required.

The study was conducted by DSI from 1992 to 1997, on the average Biochemical Oxygen Demand (BOD5) of Buyuk Melen River, $3.32 \mathrm{mg} / \mathrm{l}$ and the average load value 4,755 t/year, and according to these values in terms of BOD5 value and continuous water quality class I. The average value of COD (Chemical Oxygen Demand) is $25.43 \mathrm{mg} / \mathrm{l}$. Meanwhile the value of the annual COD load is 35,709 t/year from Buyuk Melen River into the Black Sea. Microbiological evaluation of Buyuk Melen River shows water quality of class II and III. The average Total Sus pendent Solid (TSS) is $120.3 \mathrm{mg} / \mathrm{l}$. The highest measured sediment from erosion in Buyuk Melen River by sediment transport of the Black Sea per year is $178,284 \mathrm{t}[4,6]$. 
Buyuk Melen of water was quite a high value for a year average TSS $190.5 \mathrm{mg} / 1$ [7]. The TSS annual average value of Asar Stream is $1,000 \mathrm{mg} / \mathrm{l}$. This means that Asar Stream area sand pits, and in viaduct of feet construction works are in progress for the Bolu Mountain tunnel of TEM motorway.

The differences in pollutant loads between domestic and industrial sources are even more pronounced for BOD5 and TSS parameters, where domestic loads are approximately three and ten times higher than the industrial loads, respectively. The difference in BOD5 loads is due to the fact that the food industries which account for a high percentage of the total industrial wastewater and the total industrial load in the watershed, have low BOD5 to COD ratios.

As a result, of the water quality class have Kuku Melen River of $2^{\text {nd }}$ and $3^{\text {rd }}$ of Asar Stream, and Aksu and Ugur streams of $1^{\text {st }}$ class. The Buyuk Melen water quality is evaluated to be $2^{\text {nd }}$ of the basin in case of the drainage channel [7]. In groups $\mathrm{A}$ and $\mathrm{C}$ parameters in the river water is class IV of Melen regulator in upstream, and the pollution is very effective distributed loads are the river system of the Buyuk Melen [35].

Ugur and Aksu rivers flow rates increase with the melting snow waters. They are not affected by pollution from industrial and residential areas for the water quality status is $1^{\text {st }}$. Kucuk Melen is polluted by residential areas and industrial plants in the region. This results in the water quality class $2^{\text {nd }}$. The Wastewater Treatment Plant that Düzce contained in the central part of the basin during periods of inactivity due to maintenance is exacerbated by pollution [7]. Discharge of Melen River as $1.7 \mathrm{~km}^{3} /$ year, industrial pollution loads have generally been total chromium 95.96 t/year, while cadmium 28,726 t/year, respectively [36].

Domestic wastewater produced at the facilities is calculated using a unit flow rate of $50 \mathrm{l} / \mathrm{ca}$.day [37] and the total wastewater flow rate generated by the industrial facilities is calculated by the sum of industrial process wastewater and domestic wastewater.

In addition to the pollution load of individual industries, their locations are an important subject in the Integrated Protection and Water Management in Melen Watershed. The pollutant loads from point sources alone are not enough for the evaluation of the pollution in Melen Watershed. The preliminary results for diffuse pollution loads indicate that the point sources account for $35 \%$ and $40 \%$ of the total nitrogen and phosphorus loads, respectively [34]. Although the diffused sources seem to be more important in the pollution loads, due the problems related to the management and control of diffuse pollution, treatment and hence the control of point sources may provide a better or at least a faster solution to the pollution problem in Melen Watershed [38] .

\section{CONCLUSIONS}

As this study suggests, it is possible to find a solution to multifaceted environmental problems through interdisciplinary efforts. Nowadays, the environment faces much more pollution than ever as a result of rapid industrialisation and urbanisation. Considering the fact that it is impossible to conduct a complete and thorough study on land through field work alone, it is inevitable that such means as GIS and remote sensing have to be employed.

This study aims at identifying and assessing temporal variations in the characteristics of The Buyuk Melen Watershed Basin by means of Landsat satellite images. Recently, many of the problems resulted from a growing human population moving into the natural environment. Because of the increase in the rate, reflected in the carrying capacity of the natural environment and the speed of the process of self-renewal, the rate of natural disasters has increased accordingly. This is the biggest factor that causes loss, improper uses of the land. 
Geological, geomorphological and structural features of the water basin, the structural mechanism (tectonic, climatic and/or human factors) were thought with increase the interaction between the mechanical system to increase the shear strength of the plant roots. That trees on the hillside by loads and loads of pressure by the wind on the hillside they transmit, and of the roots approach to ensuring that conservation can be explained by inhibit corrosion. Therefore, vegetation, leaves, roots and dimensions of the hydrological-mechanical interaction within the cycle of development is another important positive or negative effect on formation of the landslide. Buyuk Melen Watershed and in the vicinity, as well as the destruction of natural vegetation and slopes were ranging morphodynamic landslide processes and have made it more susceptible to wear.

Due to intensed tectonic activity in the region, the secondary structure consists of fracture-fractured-porous surface waters in this system than for the rain water moves rather slowly. And to comply with the conditions of the geological structure and the lower levels of aquifer environmental ground water table is reached. The flow of water in the basin was quite large by stream of the river between the rocks and pebbles by underground streams form the basis of the river.

\section{REFERENCES}

1. Altuntas, C. and Corumluoglu, O., Digital Image Processing in Remote Sensing Images, and RSImage Software, Selçuk Üniversitesi 30th Anniversary Symposium of Geodesy and Photogrammetry in Engineering Education, 16-18, Ekim, 2002, Konya, (in Turkish).

2. Tunay, M. and Atesoglu, A., Analysis of Changes in Vegetation Biomass about Amasra and Nearby Places Using Multitemporal and Multisensor Satellite Data, Journal of The Bartin Faculty of Forestry, Vol. 10, No. 13, pp 71-79, 2008, (in Turkish with English abstract).

3. Seker, D. Z., Tanık, A. and Ozturk, I., Application of GIS for The Watershed Management Studies, TMMOB Conference of Geographical Information Systems (02-06 Kasim 2009), 2009, İzmir, (in Turkish with English abstract).

4. Efelerli, S. and Oktas, S., The Raw Water Quality Criteria of Melen with Sakarya rivers as The Availability and Comparison of Drinking and Process Water of Istanbul, Proceedings of Water Congress and Exhibition 109, 126, 1997, (in Turkish with English abstract).

5. Watershed Protection Plan, Buyuk Melen Watershed Integrated Protection and Water Management Master Plan, Istanbul Teknik Universitesi, Department of Environmental Engineering, Istanbul, Ocak, 2008, (in Turkish).

6. Efelerli, S., Gerek, C. and Oktaş, S., Substance Transport of Sediment from the Sakarya River with Melen Creek into the Black Sea, and Pollution Loads, Symposium of DSI Quality Control Techniques, Balıkesir, 1997, (in Turkish).

7. Sumer, B., Ileri, R., Şamandar, A. and Sengorur, B., Water Quality in the River Büyük Melen and its Branches, Ekoloji, Vol. 10, No. 39, pp 13-18, 2001, (in Turkish with English abstract).

8. Singh, M., Sharma, M. and Tobschall, H. J., Weathering of the Ganga Alluvial Plain, Northern India: Implications from Fluvial Geochemistry of the Gomati River, Applied Geochemistry, Vol. 20, pp 1-21, 2005, http://dx.doi.org/10.1016/j.apgeochem.2004.07.005

9. Pehlivan, R. The Effect of Weathering in the Buyuk Melen River Basin on the Geochemistry of Suspended and Bed Sediments and the Hyrogeochemical Characteristics of River Water, Duzce, Turkey Journal of Asian Earth Sciences, Vol. 39, pp 62-75, 2010, http://dx.doi.org/10.1016/j.jseaes.2010.02.011 
10. Gedik, I. and Aksay, A., Scale: 1/100.000 Maps of Turkey Geological, Adapazar1-G25 Paftas1 No. 32, Geological Studies Office General Directorate of Mineral Research, Ankara 40p., 2002, (in Turkish with English abstract).

11. Yergok, A. F., Akman, Ü., Keskin, I., Ipekci, E., Mengi, H., Karabalik, N. N., Umut, M., Armagan, F., Erdogan, K., Kaymakci, H. and Cetinkaya, A., Geologic Report of Western Black Sea Region I. 8273, Geological Studies Office General Directorate of Mineral Research, Ankara, 237p., 1987, (in Turkish).

12. Pehlivan, S., Bilginer, E. and Aksay, A., Scale: 1/100.000 Maps of Turkey Geological, Adapazar1-G26 Paftası No. 33, Geological Studies Office General Directorate of Mineral Research, Ankara 28p., 2002, (in Turkish with English abstract).

13. Timur, E. and Aksay, A., Scale: 1/100.000 Maps of Turkey Geological, Eregli-F24 ve F25 Paftaları No:26, Geological Studies Office General Directorate of Mineral Research, Ankara 11p., 2002, (in Turkish with English abstract).

14. Altun, I. E. and Aksay, A., Scale: 1/100.000 Maps of Turkey Geological, Eregli-F26 Paftas1 No:27, Geological Studies Office General Directorate of Mineral Research, Ankara 17p., 2002, (in Turkish with English abstract).

15. Ketin, I., Uber die Tektonisch-Mechanischen Folgerungen aus den Grossen Anatolischen Erdbeben des Letzten Dezenniums, Geol.Rudsch, Vol. 36, pp 77-83, 1948, http://dx.doi.org/10.1007/BF01791916

16. Şengör, A. M. C., The North Anatolian Transform Fault: Its Age, Offset and Tectonic Significance, J. Geol. Soc. Lond., Vol. 136, pp 269-282, 1979, http://dx.doi.org/10.1144/gsjgs.136.3.0269

17. Novak, I. D. and Soulakellis, N., Identifying Geomorphic Features using LANDSAT-5/TM Data Processing Techniques on Lesvos, Greece, Geomorphology Journal, Vol. 34, pp 101-109, 2000, http://dx.doi.org/10.1016/S0169-555X(00)00003-9

18. Kumanan, C. J., Remote Sensing Revealed Morphotectonic Anomalies as a Tool to Neotectonic Mapping-Experience from South India, 22nd Asian Conference on Remote Sensing, Centre for Remote Imaging, Sensing and Processing (CRISP), National University of Singapore; Singapore Institute of Surveyors; Asian Association on Remote Sensing, 2001.

19. Hung, L. Q., Dinh, N. Q., Batelaan, O., Tam, V. T. and Lagrou, D., Remote Sensing and GIS Based Analysis of Cave Development in the Suoimuoi Catchment (Son La-NW Vietnam), Journal of Cave and Karst Studies, Vol. 64, No. 1, pp 23-33, 2002.

20. Leech, D. P., Treloar, P. J., Lucas, N. S. and Grocott, J., Landsat TM Analysis of Fracture Patterns: A Case Study from the Coastal Cordillera of northern Chile, Int. J. Remote Sensing, Vol. 24, No. 19, pp 3709-3726, 2003.

21. Gorcelioglu, E., Gunay, T., Karagul, R., Aksoy, N. and Basaran, M. A., West Black Sea Flood of Causes on 19-21 May1s 1998, Precautions of required to be taken and Recommendations, Scientific Committee Report, TMMOB Chamber of Forest Engineers Pub. No.2, Ankara, 1999.

22. Lillesand, T. M. and Kiefer, R. W., Remote Sensing and Image Interpretation, 4th ed, John Wiley and Sons, Inc., USA, ISBN: 0471255157, 2001.

23. Yıldırım, Y., Büyüksalih, G. and Oruç, M., An Investigation of Industrial Plant Pollution Using Satellite Imagery as a Tool in Zonguldak Cost, Topographic Mapping from Space, ISPRS Volume Number: XXXVI-1/W41, February 14-16, 2006, Tübitak-Bilten, Ankara, Turkey, 2006.

24. Campbell, J. B., Introduction to Remote Sensing, The Guilford Pres, 1987.

25. Sunar, F. and Kaya, T., Rectification and analysis of satellite images, Computer Applications in Civil Engineering, V. Sетроzуumu, İTÜ, İstanbul, 1996, (in Turkish with English abstract). 
26. Welch, R. and Usery, E. L., Cartographic Accuracy of Landsat-4 MSS and TM Image Data, IEEE Transactions on Geoscience and Remote Sensing, GE-22, 3, pp 281-288, 1984, http://dx.doi.org/10.1109/TGRS.1984.350622

27. Janssen, J. A. M., Monitoring of Salt-marsh Vegetation by Sequential Mapping, Ph.D dissertation, University of Amsterdam, 2001.

28. Baatz, M. and Schäpe, A., Multiresolution Segmentation-an Optimisation Approach for High Quality Multi-scale Image Segmentation, AGIT Symposium, Salzburg, 2000.

29. Oruc, M., Marangoz, A. M. and Büyüksalih, G., Comparison of Pixel-based and Object-oriented Classification Approaches Using LANDSAT-7 ETM Spectral Bands, ISPRS XXth Congress, Istanbul, 2004.

30. Charles, M. S., Vicki Z. and Debbie, F., Geopositional Accuracy Assesment Of Earthsat Geocover Landsat Orthorectified Imagery, ASPRS Annual Conference Proceedings, 2004.

31. Panizza, M., Environmental Geomorphology, Development in Earth Surface Processes 4, Elsevier Press, p 268, 1996.

32. Guzzetti F., Carrara A., Cardinali M., and Reichenbach P., Landslide Hazard Evaluation: An Aid to a Sustainable Development, Geomorphology, Vol. 31, pp 181-216, 1999, http://dx.doi.org/10.1016/S0169-555X(99)00078-1

33. Gorum T., Using Geographic Information Systems and Statistical Methods Landslide Sensitivity Analysis: Melen Strait and Near The Environment, İstanbul Üniversitesi Thesis of MSc, 2006, (in Turkish with English abstract)

34. Ozturk, I., Tanık, A., Seker, D. Z., Gurel, M., Erturk, A., Ekdal, A. and Tavsan, C., Büyük Melen Watershed Integrated Protection and Water Management Master Plan, Water Quality Draft Feasibility Report, İstanbul, 2007.

35. Şamandar, A., Water Quality Modelling in Big Melen River and Its Tributaries, Ph.D. Thesis, Sakarya Üniversitesi, Turkey, 2004, (in Turkish with English abstract).

36. Final Project Report, GEF National Protection and Management Routine Pollution Monitoring Project about the Monitoring of Land-Based Pollutants, Bathing Water and Drinking Water Quality, Prepared by Research Center of Environment in Ondokuz Mayıs University; Project Leader H. Buyukgungor, Samsun, Turkey, 1997.

37. Kerestecioğlu, M., Görgün, E., Schack, U., Germirli Babuna, F., Erzi, İ., Cakmakci, M., Ekdal, A., Aydin, E., Gronbech Jensen, B., Knudsen, J. F. and Kinaci, C., Technical Assistance for Environmental Heavy-Cost Investment Planning, Turkey: Dilovası Industrial Organized District Wastewater Management Project Feasibility Study, Design Criteria Report, 2004.

38. Pehlivanoglu Mantas, E., Aydin, E., Insel, G., Ozgun, H., Cakmakci, M., Ozturk, D. C., Akca, L., Cokgor, E. U. and Ozturk, I., Conceptual Approach for the Determination of Point Sources in Melen Watershed, In: International River Basin Management Congress, 22-24 March, Antalya Turkey, Book of Proceedings, Vol.1, pp 256-272. 